\title{
A resource-efficient and sufficient future mobility system for improved well-being in Europe
}

\author{
Moritz Kammerlander ${ }^{1}$ - Karin Schanes ${ }^{3}$ - Franziska Hartwig ${ }^{1}$ - Jill Jäger ${ }^{5}$. \\ Ines Omann $^{2} \cdot$ Michelle O'Keeffe $^{4}$
}

Received: 15 March 2015 / Accepted: 22 June 2015 / Published online: 10 July 2015

(C) The Author(s) 2015. This article is published with open access at Springerlink.com

\begin{abstract}
A transformation of our current transport system and individual mobility behaviour is an essential prerequisite for attaining a desirable future that enables a life within environmental boundaries ("safe operating space") and higher well-being at the same time. Accordingly, this paper focuses on the potentials of a resource-saving, sustainable transport system with reduced, but still satisfactory, mobility. To achieve the vision of resource-efficiency in Europe, a new understanding of mobility is needed: "the mode of travel is the reward of the journey", meaning that it is not about travelling fastest and frequently, but unhurried (easy-going), infrequently and sustainably. We describe a socially inclusive and innovative transport system that could achieve this vision and discuss the kinds of policy measures that would be required to implement it. Changes are required in many areas including values, preferences, infrastructure, technology, governance and the economy.
\end{abstract}

Keywords Resource-efficiency · Sustainable mobility · Sustainable development visions and pathways $\cdot$ Policies . Eco-innovation $\cdot$ Smart cities

Moritz Kammerlander

moritz.kammerlander@seri.at

Sustainable Europe Research Institute (SERI), Vienna, Austria

2 Helmholtz Zentrum für Umweltforschung (UFZ), Leipzig, Germany

3 Institute of Ecological Economics, WU Vienna University of Economics and Business, Vienna, Austria

4 Institute for Sustainable Resources, University College London (UCL), London, UK

5 Independent Scholar, Vienna, Austria

\section{Introduction and current dilemma of human mobility}

Historically, spatial mobility has been a crucial characteristic of human development (migration, the exchange of attitudes, values and knowledge or the spread of wealth) and civilisation (industrial revolution, the nature of wars, globalisation or landsealing). While mobility in its early stage was rather characterised by self-sufficiency, sustainability ("natural or organic powered") and a low level of transportation, as well as shared and slow travel, present mobility is usually the opposite. For almost a century our understanding of mobility as a mainly fossil-fuel powered transportation determines our daily life settings, urban and spatial planning. Accordingly, systems of provision (e.g., infrastructure, road networks and mobility options offered) [1] as well as our work- and leisure-travel behaviour have been designed on the principle of individual motorised mobility. This affects consumption choices and behavioural practices [2]. For instance, a public transport system of poor quality implies a low usage; a lack of sustainable mobility infrastructure and options offered (e.g., cycle lanes, sharing schemes or mobility plans) results in "car-addiction" [3]; or shifting shopping facilities out of the city triggers car travel and the economic dying of city centres. As a consequence, our mobility behaviour and means have become responsible for massive environmental (e.g., air pollution, climate change, bio-diversity loss and damage to eco-systems, land-waste and numerous road kills ${ }^{1}$ of living creatures ${ }^{2}$ ) and societal harm (e.g., reduced health and quality of life, social exclusion due to transport costs, availability

\footnotetext{
${ }^{1}$ Cf.http://ec.europa.eu/eurostat/tgm/table.do?tab= table\&init $=1 \&$ language $=$ en\&pcode $=$ tsdtr 420 \&plugin $=1$

${ }^{2} \mathrm{Cf}$. http://www.vcoe.at/de/presse/aussendungen-archiv/ details/items/vcoe-im-vorjahr-kamen-fast-25000-hasenunter-die-raeder-27032013
} 
and means, a capitalistic globalisation stimulating commuting and often global trade or goods transport that is not satisfying a demand).

As long as present mobility continues to rely on fossil fuels and is achieved mainly through individual motorised vehicles, geographical and societal transportation hotspots like Europe will face many transportation-related challenges. Addressing and coping with these challenges is a very critical and pressing endeavour that requires a transformation of transportation with respect to both understanding and performance (mobility behaviour and practices) [4]. We argue in this paper that a transformed transportation system should be multi-modal, sustainable, affordable, inclusive and shared. Alternative sustainable developments such as e-mobility based on renewable energy, improved public transport schemes, sharing and pooling platforms, multi-modal transport schemes, sustainable individual mobility and pro-active citizens could be of particular relevance in this regard.

The purpose of this paper is to present a holistic vision of future mobility in Europe, which is feasible within a safe operating space $[5,6]$, is sufficient in its means, efficient in its performance and inclusive in its availability. Through the application of a backcasting approach [7], to achieve a vision of a sustainable future developed by experts in a participatory setting, we develop a pathway from the current situation. The vision is of future transport in Europe enabled and maintained by a strong civil society (bottom-up), meeting the needs of many and contributing to a higher well-being for all. The pathway to achieve this vision is then discussed followed by a presentation of possible transition challenges and potential key policies and governance approaches to overcome these challenges. Finally, windows of opportunity, critical issues and related research needs are discussed.

In contrast to many other discussions about sustainable futures, this vision tries to go beyond conventional perspectives and mainly technological based approaches. Its basic idea is rooted in the participation and engagement of citizens, bottom-up processes of niches, new businesses and management strategies and responsible governance. It highlights rather a low-carbon, conscious and decelerated multi-modal mobility assisted by small-scale technological innovations applied in cooperation and performed by sharing. Through combining and adapting social and technological innovations (e.g., the use of ICT for mobility means and services or the use of the internet for the exchange of practices and opportunities) the frequency of rebound-effects can be reduced to a minimum.

\section{Present situation and expected prospective development (BAU)}

Never before have so many people and goods been transported globally. Technological innovations, multi-modal transport infrastructures and the relatively low cost of transport enable a high level of individual mobility (business and leisure). As a result transport is responsible for at least one third of global $\mathrm{CO}_{2}$ emissions [8-10], an increase of air pollution and associated health problems [11-14] and declining quality of life in urban areas $[14,15]$. In particular, densely populated areas like Europe are characterised by heavy traffic and related air pollution [11, 14]. Individual mobility by car still predominates in the modal splits across Europe. ${ }^{3}$ Comparably low prices of fossil-fuel passenger and freight transport stimulate travelling by airplane or shipping goods globally, instead of travelling by train [16] or shopping locally. Current economic and societal developments influence the state of mobility in various ways. For example, globalisation and the economic crisis stimulate outsourcing of production and movement of jobs, which has impacts on regional depopulation, commuting, urbanisation and segregation (higher building prices). Across Europe the need to commute is spreading ("survival-driven mobility"), ${ }^{4}$ leading to massive congestion. Here, mobility loses its actual meaning.

Even though car-sales rates and aspirations for carownership among the youth in urban areas are shrinking $[17,18]$, European cars per household ${ }^{5}$ (independent of the particular income level) $[19,20]$ and transport-related emissions are growing [21]. The "digital revolution" of ICTs (Information and Communication Technologies), advancing e-commerce, tele-work or video conferences as real alternatives to conventional work performance, has only minor influence on the reduction of work-related mobility (commuting and business trips) [22].

Recently the use of ICTs during travelling, especially in the case of driving cars, has become a major problem for maintaining secure and safe urban road traffic. Traffic accidents due to multi-tasking and the use of ICT devices are rapidly growing [23]. Nonetheless, ICTs contribute at least to the social inclusion of mobility-impaired and -constrained people [24]. Similarly, governmental and technical resourceefficiency measures have been insufficiently effective. For instance, the actual efficiency of new engines or power units depends on its form of drive (e.g., fuel, diesel, gas or electricity), application and use $[25,26]$. In comparison to older, lighter and simple operating cars, present heavier and bigger vehicles equipped with a mass of electronics demand much power/energy in operation, are more resource-consuming in production and, depending on the particular use, new cars are comparably inefficient [27]. Improvements of renewablepowered vehicles (e-mobility) and infrastructure (network of

\footnotetext{
${ }^{3}$ Cf. http://www.epomm.eu/tems/index.phtml

${ }^{4}$ Cf. http://www.zeit.de/2013/13/pendeln-gesundheitsrisikeninterview-schneider

${ }^{5} \mathrm{Cf}$. http://ec.europa.eu/eurostat/tgm/table.do?tab= table\&init $=1 \&$ language $=$ en $\&$ pcode $=$ tsdpc $340 \&$ plugin $=1$
} 
solar-generated charging stations) are promising developments with regard to the replacement of fossil-fuel-powered vehicles and enabling multiplier-effects as well as closed resource consumption loops.

It becomes increasingly evident that if Europeans continue along this business-as-usual path, they run the risk of producing even higher levels of socio-economic and environmental changes with disastrous consequences. Hence, a transformation of the European transportation system is not only desirable, but in fact is urgently needed.

The following vision was developed through an extensive literature review of current existing vision documents and a vision workshop (July 2013) and stakeholder workshop (December 2013) within the EU-supported project: "Policy Options for a Resource Efficient Economy" (POLFREE). ${ }^{6}$ During the first workshop, the elements of a vision for a resourceefficient Europe in 2050 were assembled. The vision was then presented to a group of stakeholders, including representatives from policy-making, business and civil society as well as other experts on resource efficiency, who discussed the elements and through a participatory workshop process agreed on the final composition of the vision. Subsequently, three possible pathways to achieve the vision have been elaborated by the project team and presented to stakeholders (June 2014). In this paper, we focus on the pathway in which large-scale involvement of civil society, as opposed, for example, to top-down governmental regulation, achieves the vision.

The aim of the envisioning process was to deliver an image of a sustainable and desirable future Europe that uses resources in a much more efficient and sufficient manner. This image of the future "that we want" can then stimulate discussion among all stakeholders about the transformation necessary to achieve it.

\section{Vision of a sustainable mobility in Europe}

In 2050 Europeans have adopted a new understanding of mobility: "the mode of travel is the reward of the journey". Being mobile is not about travelling fast and frequently anymore, but about travelling patiently, advisedly and sustainably. People are now aware of the "real costs" of unsustainable transportation for humans and the environment.

Based on this new understanding, mobility behaviour and practices have changed dramatically. The "attitudebehaviour-gap" still exists but on a much lower level than in present times. In particular as a result of participatory governance, people are now more willing to adapt their behaviour towards a more resource-saving lifestyle. They are more aware about the limits of planet earth and the consequences of their behaviour towards

$\overline{{ }^{6} \text { https://www }} \cdot$ ucl.ac.uk/polfree the environment. Due to this new understanding of mobility, which has brought about a fundamental transformation of the European transport system, people are now living well and within planetary boundaries [6]. The overall effect and the societal meanings of mobility are seen from a new perspective: the importance of being mobile for social inclusion and participation in the social and cultural daily life of poorer, elderly and handicapped individuals is recognised strongly. Mobility is accessible and affordable for everyone, managed by new systems of provision with the help of ICTs and by the application of low-carbon technologies. There are still cars, but they are now powered by a mix of electricity, hybrid engines and renewable fuels. This has resulted in a radical improvement of the environmental and social performance of Europe's transportation.

In-line with Europeans' emission goals from 2015 [28] transport emissions in 2050 have been reduced by $60 \%$ from 1990 levels [8]. The transportation sector no longer counts as a major source of emissions, air pollution, noise and health problems. The total traffic volume in Europe has decreased significantly, but the new transportation system is sufficient in its means, efficient in its performance and inclusive in its social impacts. Moreover, the EU's vulnerability to oil supply and prices has been reduced considerably through reliance on renewable sources.

In 2050 cities are attractive places to live. Urban designers are now aware that determinants, such as access to public transport, green space and local amenities, can enhance the health and well-being of residents. New forms of sustainable urban mobility have changed peoples' mobility behaviour radically and made cities much greener, cleaner and quieter places. Mostly people now live close to their work places and everyday service facilities. They work less hours and spent more time in locally- or home-based offices. Teleconferencing largely replaces face-to-face meetings. Therefore, commuting and frequent travelling for workrelated purposes are no longer common practice. Telework has led to a better work-life balance and lower commuting stress [29].

In 2050 only very few Europeans still own cars privately, and the number of private cars per household has decreased. Conventionally powered cars are almost absent in urban areas [8]. Urban goods and freight transport is usually done by cargo bikes ${ }^{7}$ for small- to medium-sized goods and by low- or zero-emission lorries. Urban spaces formerly devoted to cars have been transformed to green areas, cycling lanes and pedestrian zones. As a

\footnotetext{
${ }^{7}$ Cf. http://www.christianiabikes.de/; http://www.eltis.org/ index.php?id=13\&lang $1=$ en\&study_id=3015 and http:// www.eltis.org/index.php?id=56
} 
consequence, urban mobility is now preferably performed by cycling and walking. This contributes to the health and overall quality of life of all inhabitants. Sharing cars with neighbours, friends and family has become common practice. New sharing-systems and forms of collaborative consumption have emerged all over Europe and contribute to significant reductions in vehicle ownership [30] and a higher intensity of usage.

In general, people have shifted their preferences from individual motorised mobility to shared, sustainable and more integrated modes of travel. In 2050 the public transportation system has been expanded significantly. It now includes low-carbon buses, trams and metros, but also public bike-sharing facilities, public renting services for shared electric vehicles and transport on demand for disabled people. Due to new intermodal transport infrastructure solutions, using the public transportation system has become much more efficient and comfortable. Moreover, it is now free and available for everyone.

In 2050 vehicles for passenger and freight transport are not motorized by conventional fuels, but by a mix of renewable fuels for internal combustion engines, electricity and hydrogen fuel cells. They are now smaller, lighter and use energy inputs much more efficiently than it was previously the case. Especially in rural areas, where the availability of public transportation is more limited, electric vehicles largely replace conventionally fuelled cars.

In addition to clean technologies, efficiency improvements through changes in logistic organisation have been achieved. A large part of European's international passenger and freight transportation has been transferred to the railway. For Europeans, taking the train has become the fastest, most economical and comfortable option of travelling long distances. Aviation transport is very expensive and the demand for long-distance passenger and freight transportation has decreased drastically. Leisure-time preferences have also changed. People enjoy travelling slowly and spending holidays in local destinations. Overseas trips have become once-in-a-life-time experiences.

\section{Pathways to a future mobility in Europe}

The transformation of our current transport system and individual mobility behaviour to achieve the vision can be achieved only through a holistic perspective on mobility and a combination of varying strategies. Ambitious reductions in greenhouse gas emissions of the transport sector require both new technologies and behavioural changes.

Motivated by consumers' demand and supported through public sustainability funding schemes, the automotive and fuels industries continuously increase efforts in the development of low-carbon vehicle and fuel technologies, including greatly improved vehicular fuel efficiency and light-weighting [31]. Investments in $R \& D$ to foster low- or zero-carbon technologies, designs and materials provide a driving force for innovative developments [32]. Measures increase efficiency of the internal combustion engine (ICE) and the diffusion of vehicles powered by hydrogen [33], electricity stored in batteries [34, 35], gaseous fuels such as liquefied natural gas (LNG), and compressed natural gas (CNG) [36]. The expansion of the corresponding charging infrastructure ${ }^{8}$ triggers a rapid and comprehensive uptake of the new technologies. For example, technologies such as photovoltaic can be used and implemented by almost everyone in a very easy way. Thus, it is feasible to provide a decentralised charging network quite simply and quickly by involving regionally available social(citizens and business at site) and infrastructure (e.g., solar networks of $\mathrm{SMEs}^{9}$ ). Thereby new local resource circles are created, which will contribute to the resilience (e.g., energy independence) and prosperity (e.g., more jobs due to energycost savings) of the region.

Technological innovations and developments have attracted considerable interest, but the sole application of such measures could not achieve substantial reductions of emissions by 2050 [37]. With regard to our vision (VisionSection, above), what is even more important is an approach that brings more than only technological improvement. Thus, the implementation of soft measures (e.g., information, dissemination, awareness, test-tickets, guidance, mobility trainings on various mobility modes or in using ICT-mobility services) for low-carbon behavioural alternatives is an important mitigation option for $\mathrm{CO}_{2}$ emissions arising from transport. Measures to achieve reductions in overall travel demand (trips/frequency, distance) combined with actions to lower car travel are also required. Of particular importance in this regard are land-use policies and general improvements of the physical infrastructure for environmentally friendly travel modes.

A transformation of individual mobility is achieved by improving public transport and making it more accessible, comfortable, safer and more equitable. The key elements include amended real time information and marketing, better passenger infrastructure, improvements to vehicles and service quality, service frequency, integrated ticketing and no fares. Smart intermodal transport infrastructure solutions link railways, roads, biking lanes and walking ways and make an interchange between transport modes seamless and convenient for users. Communication strategies that comprise easily comparable information regarding the costs and journey times of

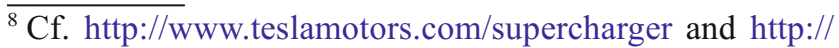
www.presseportal.de/pm/82208/2552882/tesla-motorspresents-supercharging-at-iaa-and-announces-plans-foreuropean-network-expansion

${ }^{9} \mathrm{Cf}$. http://www.gfb-greensolutions.at/projekte/gfb-netzwerk. php
} 
different transport options, together with comparable information for a car journey, further promote behavioural changes towards widespread use of intermodal options [38].

To encourage more walking, people need to modify their journey patterns and make shorter trips. This implies new and demand-oriented land use policies and integrated spatial planning regulations that ensure that facilities such as shops, pubs, schools and banks are close to where people live and are more accessible [39]. Investments in nice and safe walking routes help to make short distance trips more attractive for walking [40] but contribute also to the reduction of the influence of vested interests [41]. It is recognised that only a strong emphasis on safer and appealing neighbourhoods and secure crossings along with wider, better-maintained and cleaner pavements encourage walking [42]. An increased cycling mode share is the result of an increased willingness and demand of the citizens and of governmental and local authority investment in physical infrastructure, such as high quality network of cycle routes, convenient and safe bicycle parking facilities and strong public campaigns for cycling (including trainings, re-pair and maintaining services) [43, 44]. Shared bike facilities further trigger the use of cycling by more citizens [45]. Detailed Local Transport Plans encourage the development of major cycling projects. Parking restrictions in inner cities free up space for wider pavements bicycle lanes and parking opportunities with offering self-service implementations (e.g., air pump stations). The new system is far more equitable, since it is cheaper than a car-based system and facilitates social inclusion of previously marginalised people (disabled, elderly, people without a drivers licence, etc.). Consequently, the better the system of provision (service and infrastructure), the more people will increase their modal share for bicycles. Nevertheless, the implementation of soft measures such as well-planned information and awareness campaigns (e.g., explaining the negative impacts of fossil-fuel based mobility on health, environment and land-use) as well as marketing and promotion of cycling (e.g., elucidating the multiplier benefits like pro health and environment or the cost savings) is essential in order to achieve a successful and long-lasting shift towards cycling. In proceeding on this strategy, the behavioural gap related to individual mobility is reduced.

The implementation of a compact housing structure and holistic urban development strategies that favour a mixeduse development $[12,46,47]$ leads to higher walking and cycling rates and a decrease in the aggregate travel demand [48]. For education, commerce, health and public services, new rules are established with regard to the location of new premises, based on the concept of accessibility. Holistic urban development strategies that take an integrated, participatory governance approach and support the emergence of regional clusters have driven the emergence of small-scale production and settlement structures. Local shopping and entertainment facilities as well as recreational and educational centres become more attractive. Moreover, regional cluster development has supported the closing of economy, resources and consumption circles.

All activities, including work become regionally decentralised, but locally settled. The huge share of work-related mobility and commuting is decreased by implementation of sustainable work-travel- and mobilityplans for companies, businesses and institutions. In addition, the expansion of teleworking [49] and the application of new ICT are fostered through information for employers about multiple benefits of telework and how they can enable it. Investment in new motorways and airport infrastructures is strongly reduced. By contrast, due to an investment-shift from road to railway infrastructure, $\mathrm{Eu}$ rope has managed to build up an expanded high-speed railway system ${ }^{10}[8]$. In addition, the application of more efficient driving practices lowers energy and fuel consumption [51] and is facilitated through eco-driving campaigns, trainings, education and in-car devices. ${ }^{11}$ Similarly, car sharing, renting and pooling reduce car mileage, vehicle ownership and increase vehicle occupancy [30, 52]. Shared electric vehicle schemes are supported and established across Europe. Governments create appropriate regulatory frameworks and telecommunication infrastructure to encourage upscaling of private car-sharing initiatives [42].

Overall, there is an expansion of sustainable mobility infrastructure and the upscaling of mobility-related social innovations to address social exclusion [53]. Such strategies are of particular interest in rural areas and low populated regions, where public transport is less attractive. Social innovations, such as door-to-door, demandresponsive or micro transport schemes or home delivery services combat social exclusion while at the same time reducing the demand for travel by car.

Of course such a transformation will not happen without any constraints (technical and structural) and resistance (economic and societal). Coping with these challenges will be dependent from well-designed multi-level governance.

\section{Achieving the vision: main challenges}

Moving from the mobility situation of today to a world of sustainable mobility in 2050 faces a range of challenges. Five

\footnotetext{
$\overline{{ }^{10} \mathrm{http}: / / \mathrm{ww} w}$.livingrail.eu/rail-in-europe-2050/transportvisions

${ }^{11}$ E.g.http://www.fgm.at/index.php?ID1=2142\&mid=\&id= 2152\&sprache1=en or http://www.eltis.org/index.php?id= 13\&lang $1=$ en\&study_id=1631
} 
central challenges are presented in this section, along with potential solutions.

\section{Overcoming the fears and uncertainties that change is generating}

Although an increasing share of people feel that their lifestyles do not make them happy and recognize inter alia that overconsumption is contributing to extreme and risky environmental degradation, they do not change their way of living. This is referred to as cognitive dissonance or the belief-behaviour gap [54]. One possible reason for this gap is that the effect of changes of habits, social practices, and consumption patterns on one's well-being are uncertain and this creates fear (e.g., feeling unsafe in public transport or by using a bicycle) or is just uncomfortable. Thus, to enable a transition, people should be supported to overcome this fear by, for example, being able to experiment with a new lifestyle (participating in car-sharing schemes, using a system-wide annual ticket for public transportation, tele-working for one or two days per week, etc.), or getting to know role models that have made a shift to more sustainable mobility and are positive about their experiences. This can be supported by policies that contribute to awareness raising, for example about the health benefits of sustainable mobility and offering mobility trainings as well as policies regarding the availability and price of public transportation [55]. Furthermore, policies following up on a fundamental and widespread paradigm change of the understanding of mobility can lead to changing rules and norms that allow using the streets to walk and play instead of driving and can induce large shifts in individual mobility behaviour [41].

\section{Overcoming vested interests in the status quo}

The transition might be blocked due to vested interests in the status quo by people who have power in the current system, in particular, business people, politicians or other decision makers [41]. Especially in the case of mobility, there are strong vested interests in the automobile and fossil fuel industry [56]. Here, pressure from civil society might lead to changed perceptions of those in power. Additionally, new business-strategies (e.g., "green economy") and perspectives (e.g., "green services and solutions") and the recognition of niches (e.g., battery development, sharing platforms or ICT services) or promising developments (e.g., paradigms change of mobility and e-mobility powered by renewable energy) contribute to overcoming the barriers. This can be supported by new forms of direct democracy and public participation that has decisive power, as well as awareness-raising regarding the opportunities that sustainable mobility can provide [57].

\section{Overcoming lock-ins related to infrastructure}

Long investment cycles in infrastructures (e.g., road and rail construction) can hinder radical and rapid change. One strategy to cope with lock-ins related to a transition to sustainable mobility is to develop a long-term policy vision at the EU-level. ${ }^{12}$ Policy instruments that can contribute to reducing lock-in also include provision of financial support and (green) public procurement [58]. It is not easy to break a lock-in, because the coalitions that benefit from it are likely to resist any change [59]. Thus the development of simultaneously flexible and robust policy-mix packages is essential in order to deal with negative (rejection or environmental harm) and positive (commitment) lock-in effects [60]. Moreover, the historically nexus of social and technical connection of automobiles to everyday lives has created a lock-in situation of an "automobility culture" synonymously seen as a symbol of 'good life' and "freedom" of citizens ('citizenship of mobility') [61].

\section{Empowering eco-innovation and the development of eco-innovative goods and services}

Supporting companies to overcome internal barriers to ecoinnovation (in particular by providing eco-innovation financial support, promoting skills, and raising awareness) will enable business to grasp - more quickly - the business opportunities of the transition to sustainable mobility. Support for building up car-sharing schemes as a reliable service for sustainable mobility would accelerate the transition, as would support for other mobility-related services. In addition, low-carbon vehicles and regional-resourcecircles of mobility measures (e.g., a decentralised network of photovoltaic charger for e-mobility means) can be maintained or upscaled. Similarly, the development of ecoinnovations can be triggered by collaborations of business, research institutes and waste and disposal agencies [32].

\section{Bringing actors together to create the kind of systemic change needed}

Given that society is usually heterogenic it has to be taken into consideration that there will always be someone who is disappointed about any measure implemented. Thus, it is important that bottom-up movements and top-down processes are interlinked, so that new institutions, production and life modes can be co-created by different actors. Currently, the mobility sector is characterized by a complex multi-level governance system with unclear and ineffective distribution of responsibilities (see Governance and key policies Section). Linking

\footnotetext{
${ }^{12} \mathrm{http}: / /$ ec.europa.eu/transport/themes/sustainable/index_en. htm
} 
the various levels requires the creation of facilitated arenas characterised by openness, appreciation and trust, where actors can meet and openly discuss their ideas, solutions and also concerns. For instance, changes and mobility-related measures could be decided on the basis of democratic votes or participatory processes with citizens. Additionally, the provision of objective and well-elaborated information gathered from various points of view is necessary in order to cover as many attitudes and perspectives as possible.

In addition to the policies that are directed at particular sectors, there are a number of key policies that are aimed at resource use in general and thus affect multiple sectors. Based on an intensive literature review and stakeholder consultations within the POLFREE project, the following list of key policies and policy actions have been identified:

\section{Governance and key policies}

How can the shift to sustainable mobility be achieved? This section aims at translating the above vision and pathway into governance mechanisms and concrete policies for the transformation. Apart from being strongly influenced by industry and business lobbies [62], various location-specific and societal issues challenge the governance of a sustainable mobility system: Different structures of mobility provision and of formal governance frameworks across countries and regions often lead to a lack of clarity about the responsibilities between different levels of governance (spatial), and end in a rather weak commitment of different mobility strategies to carbon emission reduction.

In order to cope with this profusion of different actors Marsden and Rye (2010) suggest to draw upon a multilevel governance approach to address the current devolution of authority away from formal organizations to informal organizations [63]. Such a governance approach needs to be able to follow up on sustainable mobility practices already performed by a Critical Mass [50] as well as to scale up various developments evolved from niches and grassroots movements [64, 65].

Well-designed policies are seen as key to smoothing the transition [66]. In particular at the beginning, supportive government policies and a mix of measures to promote sustainable ways of transportation and mobility behaviour are essential for the scope and success of such a transformation. In particular, a participatory approach to governance can contribute to a broad dialogue on possible trade-offs and the reduction of possible negative effects of policies. The implementation of policies to stimulate people to use alternative modes of transport include "push measures" that aim at making driving a car less attractive and "pull measures" that aim at offering alternative mobility options. "Pull measures" include measures to internalise external costs of car travel, (e.g., congestion charges or higher taxes for unsustainable modes of travel). In addition, limiting parking places and expanding pedestrian zones support the reduction of car use."Push measures" include campaigns and initiatives that support cycling, walking and using public transportation and investments in well-developed bicycle lanes, safe and welldesigned footpaths. Additionally, the implementation of affordable or even free public transport schemes in cities has proved effective in reducing car use and air pollution [67, $68] .^{13}$

A mix of these policy approaches can be applied by different measures and can address diverse individuals and various mobility issues in a comprehensive way. For instance a reduce of work-related mobility can be stimulated through "organisational" interventions providing incentives for private companies trigger the development of corporate mobility plans: the implementation of sustainable urban mobility plans (SUMPs), employee mobility plans (EMPs) and workplace travel plans (WTPs) ${ }^{14}$ public institutions ${ }^{15}$ and educational institutions (e.g., kindergartens, schools and universities) ${ }^{16}$ or workplace parking levies offer an alternative to a free parking space at work. More active promotion of the (mobility-) benefits of teleworking to employers and their staff or more flexible working hours may also constitute efficient means in reducing emissions associated with work-related mobility. Emissions could also be reduced by the provision of mobility trainings ${ }^{17}$ for sustainable modes of travel from kindergarten upwards to retired citizens, including also trainings for people with reduced mobility.

Many policy measures have been identified which would support achievement of the ambitious vision described. Based on an analysis of existing and proposed policies, the following key policies have been identified:

- Remove all environmentally harmful subsidies and reduce taxes for community/shared-ownership vehicles as well as for all businesses and companies that implement

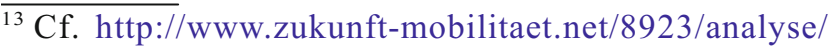
kostenloser-oepnv-tallinn-hasselt-templin-luebben/

${ }^{14}$ As for example the workplace travel plan of British Sky Broadcasting: http://www.eltis.org/index.php?id=13\&study_ id $=2747$

${ }^{15}$ As for example the mobility management concept of Heathrow Airport: http://www.eltis.org/index.php?id= 13\&study_id $=2821$

${ }^{16}$ As for example: http://www.eltis.org/index.php?id= $13 \&$ study $\mathrm{id}=3536$

${ }^{17}$ As for example: http://www.fgm.at/index.php?ID1= $2142 \& \mathrm{mid}=\& \mathrm{id}=2152 \&$ sprache $1=$ en or http://www.eltis.org/ index.php?id=13\&lang1=en\&study_id=1631
} 
employee mobility plans and/or sustainable business fleets based on hybrid, plug-in and e-mobility vehicles.

- Strengthen the requirements on Green Public Procurement (GPP) for all products with significant environmental impacts including means of tranportation.

- Reduce investment in new motorways and airport infrastructures, and increase the improvement of a high-speed train network for passengers and freight transport.

- Implement a Participatory Spatial Planning Directive to promote sustainability and well-being, giving more space to pedestrians, bicycles and public transport and shared public space.

- Introduce eco-design product standards for a circular economy and increasing efficiency of renewable electricity production and distribution (renewable charging stations)

- Investment in coordinated Research, Development and Innovation (RDI) for material, water and energy efficiency, waste prevention, sustainable mobility, urban planning, resource-light construction and low-carbon technology.

- Implement awareness campaigns and educational reforms and trainings (including mobility trainings) across the EU to integrate sustainable development.

- Support green niche markets, strengthen the feedback from consumers to producers and support systemic innovations in mobility measures

- Introduce improved monitoring methods, tools and ICTs that allow matching of mobility supply and demand and planning of multi-modal travel.

- Establish a free available and convenient intermodal public transport system as well as low to zero-energy and material-efficient transportation modes.

- Subsidise measures to increase cycling and walking infrastructure and the use of cargo-bikes (and e-bikes) for inner-city suppliers and delivery services

The implementation of such policies contributing to the improvement and quality of public transport (e.g., network, infrastructure and vehicles), sustainable mobility infrastructure (e.g., more and safer bicycle lanes and pavements) and options offered (e.g., attractive and affordable car/bike sharing/pooling schemes) can lead to substantial decreases in GHG emissions. Such a governmental strategy might result in additional positive spill-over effects, as for example: an increase in sustainable modes and simultaneously a decrease of car use; enabling cost savings and stimulating physical exercise and a healthier society or obtaining economic benefits ${ }^{18}$ for communities by an increase in home-office-practices and reduced road maintenance.

\footnotetext{
${ }^{18}$ As for example, the University of Tilburg has calculated an annually saving of 50 million Euro in the case of the Netherlands: http://www.eltis.org/index.php?ID1=5\&id=8\&home= 1\&news_id=3270
}

In general, maintaining a strong focus on raising awareness about sustainable development, mobility product-service systems, resource use and more sustainable behaviours is of important relevance. In combination with participatory approaches this strategy can lead to capacity building, knowledge exchange networks, information campaigns.

\section{Discussion \& research needs}

The vision of a future transport for Europe anticipates a societal transformation towards a sustainable mobility characterised by a combination of changes of perspectives, values and preferences as well as sharing as new practice of use and multi-level governance. The mobility concept described tries to bridge the gap between eco-innovation and shared sustainable mobility. While the development of low emissions vehicles (low-energy and material-efficient) requires investment in R\&D and infrastructure deployment (e.g., charging stations), the establishment of sharing and pooling schemes available across Europe is dependent on changes of behaviour.

Building a low carbon mobility system that provides a high quality of life will depend critically on conscious efforts and policies to enable behavioural changes. In this regard the development of benchmarking indicators based on present reallife examples instead of those achieved under laboratory conditions are of particular relevance [26]. Hence, harmonised labelling on the resource consumption of products or the sustainability of mobility vehicles which are more reliable will provide more transparent to all citizens.

In general research is needed to make concepts and elements of the vision meaningful and feasible for different level of application. Research can deliver insights about the multiplier and broader effects of sustainable modes of travel and the real improvements of transport related-technological innovations through the development of new and longer-term analysis. Taking the contribution by the use of sustainable modes travel to the reduction of transport-emission and individual (and indirectly collective) health into consideration would enable stronger economic arguments for changes of mobility.

In particular research is needed on the role of citizens and how to overcome the belief-behaviour gap or lock-in settings and on new ways of public and stakeholder participation approaches to find out what individuals really need to dare to try new lifestyles. Similarly, research can contribute to approaches on upscaling successful initiatives and measures of sustainable mobility. If properly enforced and supported by an appropriate policy-mix to ensure fair market conditions, the transformation of mobility can be a powerful in addressing environmental issues in alignment with other objectives (raising health and air quality). For instance funding of combinations of sustainable developments or "sustainable synergies" could enable and stimulate circulated economies at a small- 
scale: Local SMEs will get support and subsidies for installing photovoltaic when they will allow free and public electric charging of e-mobility vehicles on site. So it is possible to establish a bottom-up free and renewable charging network in rural areas, which supports local business and in a second step make e-mobility as an alternative already in its current state feasible. Similarly, synergies between photovoltaic powered and the generation of bio/organic-gas for charging vehicles or urban energy generation through micro sewage or drain hydro power plants for e-mobility means represent promising resource-circles.

"Overall, staying within the safe operating space requires new forms of adaptive governance and a systems perspective that recognizes the dynamic links between the social, ecological and economic system and between the different levels of our society (macro, meso, micro)" [49:10]. The vision provided in this article is a starting point to highlight the changes and developments, but also the benefits and windows of opportunities that might occur by enabling future mobility for Europe within the safe operating space $[5,6]$. The POLFREE project will continue to work with this vision using a modelling exercise to test the feasibility of different possible pathways with results available in 2015 .

Acknowledgments This article draws on research performed during the EU-supported research project "Policies for a Resource Efficient Economy" (Project no: 308371).

Open Access This article is distributed under the terms of the Creative Commons Attribution 4.0 International License (http:// creativecommons.org/licenses/by/4.0/), which permits unrestricted use, distribution, and reproduction in any medium, provided you give appropriate credit to the original author(s) and the source, provide a link to the Creative Commons license, and indicate if changes were made.

\section{References}

1. Spaargaren G (2003) Sustainable consumption: a theoretical and environmental policy perspective. Soc Nat Resour 16:687-701

2. Shove E, Pantzar M, Watson M (2012) The dynamics of social practice: everyday life and how it changes. Sage Publications, London

3. Bamberg S, Hyllenius P, Haustein S, Welsch J, Schreffler E, Carreno M, Rye T, D‘Arcier B, Zoubir A (2009) WPB final report - behaviour change models and prospective assessment. MAXsuccess: successful travel awareness campaigns and mobility management strategies, final report of work package behaviour prepared for the European commission

4. Geels WF, Kemp R, Dudley G, Lyons G (2012) Automobility in transition? A Socio-Technical Analysis of Sustainable Transport, Routledge, Ney York

5. O'Brien M, Hartwig F, Schanes K, Kammerlander M, Omann I, Wilts H, Bleischwitz R, Jäger J (2014) Living within the safe operating space: a vision for a resource efficient Europe. Eur J Futur Res Spec Issue Futur Eur 2:48. Available at: http://link.springer.com/ article/10.1007\%2Fs40309-014-0048-3
6. Rockström J et al (2009) A safe operating space for humanity. Nature 461:472-475

7. Robinson J (1990) Futures under glass: a recipe for people who hate to predict. In: "Futures", October, pp 820-842

8. European Commission (2011) White paper on transport: roadmap to a single European transport area - towards a competitive and resource-efficient transport system. Luxembourg

9. IEA (2013) CO2 Emissions from Fuel Combustion. Highlights 2013. International Energy Agency, Paris. Available at: http:// www.iea.org/publications/freepublications/publication/ co2emissionsfromfuelcombustionhighlights2013.pdf

10. OECD and ITF (2010) Reducing Transport Greenhouse Gas Emissions: Trends \& Data 2010. This document was produced as background for the 2010 International Transport Forum, on 26-28 May in Leipzig, Germany, on Transport and Innovation: Unleashing the Potential. Available at: http://www. internationaltransportforum.org/Pub/pdf/10GHGTrends.pdf

11. Kiesewetter G, Borken-Kleefeld J, Schöpp W, Heyes C, Thunis P, Bessagent B, Terrenoire E, Fagerli H, Nyiri A, Amann M (2015) Modelling street level PM10 concentrations across Europe source apportionment and possible futures. In: Atmos Chem Phys 15(3): pp 1539-1553. Available at: http://www.atmos-chem-phys.net/15/ 1539/2015/acp-15-1539-2015.pdf

12. PBL (2009) Co-benefits of climate policy. Background Studies. Netherlands Environmental Assessment Agency, Bilthoven. Available at: http://www.unep.org/transport/gfei/autotool/ understanding_the_problem/Netherlands $\% 20$ Environment $\%$ 20Agency.pdf

13. UNEP:http://www.unep.org/transport/gfei/autotool/understanding the_problem/Reducing_air_polution.asp

14. EEA (2014) Air quality in Europe - 2014 report, Luxembourg. Available at: http://www.eea.europa.eu//publications/air-quality-ineurope-2014

15. Dratva J, Zemp E, Dietrich FD, Bridevaux OP, Rochat T, Schindler C, Gerbase WM (2010) Impact of road traffic noise annoyance on health-related quality of life: results a population-based study. Qual Life Res 19(1):37-46

16. Franzen A (1998) Zug oder flug? eine empirische studie zur verkehrsmittelwahl für innereuropäische reisen. Z Soziol 27(1): 53-66

17. Kuhnimhof T, Armoogum J, Buehler R, Dargay J, Denstadli MJ, Yamamoto T (2012) Man shape a downward trend in car use among young adults - evidence from six industrialized countries. In: Trans Rev 32(6): pp 761-779. Available at: https://ralphbu.files.wordpress.com/2013/04/young-adultsinternational-travel-trends.pdf

18. Litman $\mathrm{T}$ (2006) Changing travel demand: implications for transport planning. ITE J 76(9):27-33

19. Dargay J, Hivert L (2005) The dynamics of car ownership in EU countries: a comparison based on the European household panel survey. Conference paper of the European Transport Conference, Association for European Transport (pub.)

20. Dargay J, Gately D, Sommer M (2007) Vehicle ownership and income growth, worldwide: 1960-2030. Energy J 28(4):143-170

21. European Commission (2011) Impact assessment. Accompanying document to the white paper. Commission Staff Working Paper, Belgium, Brussels

22. Wiegmanns WB, Beekman N, Boschker A, Van Dam W, Nijhof N (2003) ICT and sustainable mobility: from impacts to policy. Growth and Change 34(4):473-489

23. Kenyon S, Lyons G (2007) Introducing multitasking to the study travel and ICT: examining its extent and assessing its potential importance. Transp Res A Policy Pract 41(2):161-175. doi:10. 1016/j.tra.2006.02.004

24. Kenyon S, Lyons G, Rafferty J (2002) Transport and social exclusion: Investigating the possibility of promoting inclusion 
through virtual mobility. J Trans Geogr 10(3):207-219, ISSN 0966-6923

25. ICCT (2014) Real-world exhaust emissions from modern diesel cars: a meta-analysis of PEMS emissions data from EU (EURO 6) and US (TIER 2 BIN 5/ULEV II) Diesel Passanger Cars. Washington DC. Available at: http://www.theicct.org/sites/default/ files/publications/ICCT_PEMS-study_diesel-cars_20141010.pdf

26. Mock P, Tietge U, Franco V, German J, Bandivadekar A, Ligternik N, Lambrecht U, Kühlwein J, Riemersma I (2014) From laboratory to road: a 2014 update of official and real-world fuel consumption and $\mathrm{CO}_{2}$ values for passanger cars in Europe. The International Council On Clean Transportation (ICCT), Washington DC. Available at: http://www.theicct.org/sites/default/files/publications/ ICCT_LaboratoryToRoad 2014 Report_English.pdf

27. Van Wee B, Moll CH, Dirks J (2000) Environmental impact of scrapping old cars. In: Transp Res D 5:pp 137-143. Available at: http://www.aaben.nl/images/Milieu/TR-D\%20scrapping.pdf

28. European Commission (2015) Energy union package: the Paris protocol - a blueprint for tackeling global climate change beyond 2020. Communication from the Commission to the European Parliament and the Council, Brussels. Available at: http://ec. europa.eu/priorities/energy-union/docs/paris_en.pdf

29. Bailey DE, Kurland NB (2002) A review of telework research: findings, new directions, and lessons for the study of modern work. J Organ Behav 23:383-400

30. Martin EW, Shaheen SA (2011) Greenhouse gas emission impacts of carsharing in North America. Intell Transp Syst, IEEE Trans 12: 1074-1086

31. Modaresi R, Pauliuk S, Løvik AN, Müller DB (2014) Global carbon benefits of material substitution in passenger cars until 2050 and the impact on the steel and aluminum industries. Environ Sci Technol 48:10776-10784

32. EIO (2013) Europe in transition: paving the way to a green economy through eco-innovation. Eco-innovation observatory. European Commission, DG Environment, Brussels

33. Nemry F, Brons M (2010) Plug-in hybrid and battery electric vehicles. Market penetration scenarios of electric drive vehicles. European Commission, Joint Research Centre. Technical Note JRC 58748

34. Bauer C, Hofer J, Althaus HJ, Del Duce A, Simons A (2015) The environmental performance of current and future passenger vehicles: life cycle assessment based on a novel scenario analysis framework. Applied energy

35. Hawkins TR, Singh B, Majeau-Bettez G, Strømman AH (2013) Comparative environmental life cycle assessment of conventional and electric vehicles. J Ind Ecol 17:53-64

36. Dai Q, Lastoskie CM (2014) Life cycle assessment of natural Gaspowered personal mobility options. Energy Fuel 28:5988-5997

37. Banister D (2011) Cities, mobility and climate change. J Transp Geogr 19:1538-1546

38. Lyons G, Harman R (2002) The UK public transport industryand provision of multi-modal traveller information. Int J Transp Manag 1(1):1-13, ISSN 1471-4051

39. Hall PG, Pain K (2006) The polycentric metropolis: learning from mega-city regions in Europe. Routledge

40. Pucher J, Buehler R (2010) Walking and cycling for healthy cities. Built Environ 36:391-414

41. Hickman R, Austin P, Banister D (2014) Hyperautomobility and governmentality in Auckland. J Environ Pol Plan 16:419-435

42. Santos G, Behrendt H, Teytelboym A (2010) Part II: policy instruments for sustainable road transport. Res Transp Econ 28:46-91

43. Krizek KJ, Barnes G, Thompson K (2009) Analyzing the effect of bicycle facilities on commute mode share over time. J Urban Plan Dev 135(66):73
44. Pucher J, Buehler R (2006) Why canadians cycle more than americans: a comparative analysis of bicycling trends and policies. Transp Policy 13:265-279

45. Shaheen S, Guzman S, Zhang H (2010) Bikesharing in europe, the americas, and asia. Transp Res Rec J Transp Res Board 2143:159-167

46. Banister D, Hickman R (2006) How to design a more sustainable and fairer built environment: transport and communications. Intell Transp Syst IEE Proc 153:276-291

47. Pucher J, Buehler R, Seinen M (2011) Bicycling renaissance in north america? an update and re-appraisal of cycling trends and policies. Transp Res A Policy Pract 45:451-475

48. Giles-Corti B, Bull F, Knuiman M, McCormack G, Van Niel K, Timperio A, Christian H, Foster S, Divitini M, Middleton N, Boruff B (2013) The influence of urban design on neighbourhood walking following residential relocation: longitudinal results from the RESI DE study. Soc Sci Med 77:20-30

49. Choo S, Mokhtarian PL, Salomon I (2005) Does telecommuting reduce vehicle-miles traveled? An aggregate time series analysis for the US. Transportation 32:37-64

50. Blickstein S, Hansons S (2001) Critical mass: forging a politics of sustainable mobility in the information age. Transportation 28:347-362

51. Anable J, Bristow AL (2007) Transport and climate change: supporting document to the CfIT report. Commission for integrated transport

52. Firnkorn J, Müller M (2011) What will be the environmental effects of new free-floating car-sharing systems? The case of car2go in Ulm. Ecol Econ 70:1519-1528

53. FTA (Federal Transit Administration) (2006) Applicability of Bogotá's TransMilenio BRT system to the united states. Federal Transit Administration, Washington, Project number FL-26-7104-01

54. Clayton S, Myers G (2009) Conservation psychology understanding and promoting human care for nature. Wiley-Blackwell, West Sussex, UK

55. Wilts H, von Gries N, Bahn-Walkowiak B, O’Brien M, Busemann J, Domenech T, Bleischwitz R, Dijk M (2015) Policy mixes for resource efficiency. Work package final report (POLFREE) prepared for the European Commission

56. Paterson M (2007) Automobile politics: ecology and cultural political economy. Cambridge University Press, Cambridge

57. Hickman R, Ashiru O, Banister D (2010) Transport and climate change: Simulating the options for carbon reduction in London. Transp Policy 17:110-125

58. Foxon T (2002) Technological and institutional 'lock-in' as a barrier to sustainable innovation. ICCEPT Working Paper, Available at: http://www3.imperial.ac.uk/pls/portallive/docs/1/7294726.PDF

59. Corvellec H, Campos ZJM, Zapata P (2013) Infrastructures, lockin, and sustainable urban development - the case of waste incineration in the göteborg metropolitan area. J Clean Prod. doi:10.1016/j. jclepro.2012.12.009

60. Åkerman J, Höjer M (2006) How much transport can the climate stand? Sweden on a sustainable path in 2050. Energy Policy 34: 1944-1957

61. Urry J (2004) The 'system' of automobility. Theory, Cult Soc 21(4/5):25-39

62. Takács-Sánta A (2007) Barriers to environmental concern. Human Ecol Rev 14(1):26-38

63. Marsden G, Rye T (2010) The governance of transport and climate change. J Transp Geogr 18(6):669-678

64. Köhler J, Whitmarsh L, Nykvist B, Schilperoord M, Bergman N, Haxeltine A (2009) A transitions model for sustainable mobility. Ecol Econ 68:2985-2995

65. Nykvist B, Whitmarsh L (2008) A multi-level analysis of sustainable mobility transitions: niche development in the UK and Sweden. Technol Forecast Soc Chang 75:1373-1387 
66. Wilts H, Bahn-Walkowiak B and Bleischwitz R (2013) How to define a policy mix for resource efficiency. World Resour Forum 2013, Davos

67. Cuenot F, Fulton L, Staub J (2012) The prospect for modal shifts in passenger transport worldwide and impacts on energy use and $\mathrm{CO}$ 2. Energy Policy 41:98-106

68. van Goeverden C, Rietveld P, Koelemeijer J, Peeters P (2006) Subsidies in public transport. Eur Trans 32:5-25

\section{Online sources:}

69. http://ec.europa.eu/eurostat $/ \operatorname{tgm} /$ table. $\cdot$ o $? \mathrm{tab}=$ table $\&$ init $=$ $1 \&$ language $=$ en $\&$ pcode $=$ tsdtr $420 \&$ plugin $=1$

70. http://www.eltis.org

71. https://www.ucl.ac.uk/polfree
72. http://www.christianiabikes.de/

73. http://ec.europa.eu/transport/themes/sustainable/index_en.htm

74. http://www.presseportal.de/pm/82208/2552882/tesla-motorspresents-supercharging-at-iaa-and-announces-plans-for-europeannetwork-expansion

75. http://www.epomm.eu/tems/index.phtml

76. http://www.fgm.at/index.php?ID $1=2142 \& \mathrm{mid}=\& \mathrm{id}=$ 2152\&sprache $1=$ en

77. http://www.gfb-greensolutions.at/projekte/gfb-netzwerk.php

78. http://www.livingrail.eu/rail-in-europe-2050/transport-visions

79. http://www.teslamotors.com/supercharger

80. http://www.vcoe.at/de/presse/aussendungen-archiv/details/items/ vcoe-im-vorjahr-kamen-fast-25000-hasen-unter-die-raeder27032013

81. http://www.zeit.de/2013/13/pendeln-gesundheitsrisiken-interviewschneider

82. http://www.zukunft-mobilitaet.net/8923/analyse/kostenloseroepnv-tallinn-hasselt-templin-luebben/ 